Купріна Н.M.

доктор економічних наук, доцент кафедра обліку та аудиту

E-mail:k.natali_@ukr.net

ORCID ID: 0000-0003-4645-545X

Баранюк X.O.

доктор філософіії, старший викладач кафредра обліку та аудиту

E-mail: baranyuk.kristina@gmail.com ORCID ID: 0000-0002-3346-0332

\author{
Ступницька Т.М. \\ кандидат економічних наук, доцент \\ кафедра обліку та аудиту \\ E-mail: t.stupnitska@gmail.com \\ ORCID ID: 0000-0002-2517-2795
}

Величко О.М.

студентка 3 курсу фракультету економіки, бізнесу і контролю Одеська національна академія харчових технологій

вул. Канатна 112, м. Одеса, Україна, 65039

E-mail: velichko20012001@gmail.com

ORCID ID: 0000-0002-8591-878X

\title{
ОБОРОТНІ АКТИВИ В СИСТЕМІ УПРАВЛІННЯ ПІДПРИЄМСТВА: СУЧАСНІ АСПЕКТИ ОБЛІКУ, АНАЛІЗУ ТА АУДИТУ
}

Актуальним в сучасних умовах для ефективного функціонування підприємств є визначення напрямів управління його оборотними активами, які мають велику питому вагу в загальній сукупності активів та дефіцит власних джерел фінансування, що негативно впливає на фінансовий стан підприємства. Ефективне управління об'єктом діяльності будь-якого підприємства починається з якісного економічного аналізу, який формує його напрями, вибір інструментів та методів на підставі сформованої системи показників. Запропоновано методичний підхід до проведення фінансового аналізу оборотних активів підприємства, який охоплює не тільки аналіз стану, структури, динаміки, ефективності використання оборотних активів підприємства в цілому, але й аналіз використання окремих елементів оборотних активів, а також тривалості фінансового циклу підприємства. Обґрунтовано, що управління оборотними активами підприємства не можливе без таких інструментів управління, як фрінансовий аналіз, управлінський облік та аудит спеціального призначення, що, на нашу думку, базуються на окремих функціях управління.

Ключові слова: оборотні активи, оборотний капітал, підприємство, управлінський облік, фрінансовий аналіз, аудит спеціального призначення, інструменти управління, функції управління, показники ефрективності використання.

This work is licensed under a Creative Commons Attribution 4.0 International License http://creativecommons.org/licenses/by/4.0/

Постановка проблеми та її зв'язок 3 важливими науковими та практичними завданнями. Діяльність підприємства будь-якої галузі неможлива без ефективного управління капіталом, який вкладено в його оборотні та необоротні активи. Оборотний капітал підприємства повинен мати високу кількість оборотів, що пов'язано 3 ефективністю управління його окремими елементами, а особливе значення має саме власний оборотний капітал, який $є$ важливим джерелом фінансування даних активів підприємства, а його наявність та рентабельність, суттєво впливає на фінансовий стан підприємства будь-якої галузі.

Дослідження статистичних даних за 20162019 роки показало [1, с. 416-419], що в Україні оборотний капітал підприємств, який вкладено в його оборотні активи складає $56-57 \%$ в загальної структуpi вкладеного капіталу: у 2016р. - 57,8\%, у 2017 р. $56,7 \%$, у 2018 р. - 57,8\%, у 2019 р. 57,7\%, а в промисловості коливається від 51,5\% до 56,7\%: у 2016 р. 54,4\%, у 2017-2018 р. - 56,7\% та 55,8\% відповідно, а у 2019 р. - вже 51,5\%. Як джерело фінансування оборо- тного капіталу підприємств, власний капітал в загальної величіні капіталу мав частку більше $24 \%$ у 2016-2018 роках, але у 2019 р. склав $26,9 \%$, але у підприємств промисловості спостерігається значна менша його частка - від 17\% до майже 19 \% у 2016-2018 pp. при його зростанні у 2019 році до 24,3\%. Така динаміка власного капіталу, як джерела фінансування оборотного капіталу, що вкладено в його оборотні активи, є негативною з точки зору фінансового стану підприємств, де для нормального фінансового стану власний капітал повинен бути не менш 50\% в загальної сумі капіталу підприємства при значної частки оборотних активів в загальної їх сумі.

Оборотний капітал підприємства, який структурується та вкладено в запаси, дебіторську заборгованість, поточні фінансові інвестиції, витрати майбутніх періодів та безпосередньо самі грошові кошти $€$ необхідною умовою та джерелом фінансування діяльності підприємства та потребує вибору сучасних інструментів як в цілому, так й окремих його елементів, в системі управління підприємством. 
Аналіз останніх досліджень і публікацій. Дослідження управління оборотними активами, в які вкладено оборотний капітал підприємства, а саме, їх сутності, класифікації, методів та інструментів управління $\epsilon$ актуальними в сучасних умовах стану діяльності та функціонування підприємства та розглядались у наукових та практичних публікаціях як українських, так й зарубіжних вчених: Баумоля У., Білик М., Бланка I., Бутинця Ф., Брігхейма Ю., Буркинського Б., Бутенко А., Горового Д., Золотарьова А., Кірєйцева Г., Коновалової О., Майєрса С., Мартіна Д., Мертона Р., Міллера М., Нападовської Л., Нашкерської Г.В., Невмержицької Н., Орра Д., Осипова П., Павловської О., Притуляк Н., Поддерегіна А, Савченко А., Стоянової О., Тарасенко О., Терещенка О., Томкінса Д., Шеремета В., Фролова В. та ін., але потребують додаткових досліджень.

Формулювання цілей дослідження. Метою даної статті є дослідження аспектів застосування сучасних інструментів управління оборотними актива- ми підприємства, як важливого елементу активів, в який вкладено його власний та позиковий капітал, в системі управління підприємства 3 метою забезпечення ефективності його функціонування та управління.

Виклад основних результатів та їх обгрунтування. Ефективне управління об'єктом діяльності будь-якого підприємства починається 3 якісного економічного аналізу, який формує його напрями, вибір інструментів та методів у зв'язку з виявленими негативними та позитивними тенденціями на підставі сформованої системи показників. Аналіз стану, структури, динаміки, ефективності використання оборотних активів підприємства не можливий без такого інструменту управління [2-5], як фінансовий аналіз та, як правило використовується за методичним підходом, що наведено у табл. 1-4 на підставі даних фінансової звітності підприємства АПК за два роки [6, c. $198-200,208]$.

Таблиця 1

Аналіз складу, структури та динаміки активів підприсмства*

\begin{tabular}{|c|c|c|c|c|c|}
\hline \multirow{2}{*}{ Показники } & \multirow{2}{*}{$\begin{array}{l}\text { Код } \\
\text { рядка }\end{array}$} & \multirow{2}{*}{$\begin{array}{l}\text { Попередній } \\
\text { рік }\end{array}$} & \multirow{2}{*}{$\begin{array}{l}\text { Звітний } \\
\text { рік }\end{array}$} & \multicolumn{2}{|c|}{ Відхилення } \\
\hline & & & & абс. & $\%$ \\
\hline Всього активів, тис. грн. & 1300 & 173923 & 206316 & 32393 & 18,6 \\
\hline \multirow{2}{*}{$\begin{array}{l}\text { 1. Необоротні активи, тис. грн. } \\
\text { - в \% до активів }\end{array}$} & \multirow{2}{*}{1095} & 55293 & 79503 & 24210 & 43,8 \\
\hline & & 31,8 & 38,5 & 6,7 & $\mathrm{x}$ \\
\hline \multirow{2}{*}{$\begin{array}{l}\text { 2. Оборотні активи, тис. грн. } \\
\text { - в \% до активів }\end{array}$} & \multirow{2}{*}{1195} & 118630 & 126813 & 8183 & 6,9 \\
\hline & & 68,2 & 61,5 & $-6,7$ & $\mathrm{x}$ \\
\hline \multirow{2}{*}{$\begin{array}{l}\text { 2.1. Запаси, тис. грн. } \\
\text { - в \% до активів }\end{array}$} & \multirow{2}{*}{1100,1110} & 101411 & 116987 & 15576 & 15,4 \\
\hline & & 58,3 & 56,7 & $-1,6$ & $\mathrm{x}$ \\
\hline \multirow{2}{*}{$\begin{array}{l}\text { 2.2. Кошти в розрахунках, тис. грн. } \\
\text { - в \% до активів }\end{array}$} & \multirow{2}{*}{$1120 \div 1155$} & 5253 & 4683 & -570 & $-10,9$ \\
\hline & & 3 & 2,3 & $-0,8$ & $\mathrm{x}$ \\
\hline \multirow{2}{*}{$\begin{array}{l}\text { 2.3. Грошові кошти та їх еквіваленти, тис. грн. } \\
\text { - в \% до активів }\end{array}$} & \multirow{2}{*}{1160,1165} & 11966 & 4613 & -7353 & $-61,4$ \\
\hline & & 6,9 & 2,2 & $-4,6$ & $\mathrm{x}$ \\
\hline \multirow{2}{*}{$\begin{array}{l}\text { 2.4. Інші оборотні активи, тис. грн. } \\
\text { - в \% до активів }\end{array}$} & \multirow{2}{*}{1170,1190} & - & 530 & 530 & 0,0 \\
\hline & & - & 0,3 & 0,3 & $\mathrm{x}$ \\
\hline \multirow{2}{*}{$\begin{array}{l}\text { - у тому числі витрати майбутніх } \\
\text { періодів, тис. грн. } \\
\text { - в \% до активів }\end{array}$} & \multirow{2}{*}{1170} & - & 530 & 530 & 0,0 \\
\hline & & - & 0,3 & 0,3 & $\mathrm{x}$ \\
\hline \multirow{2}{*}{$\begin{array}{l}\text { 3. Необоротні активи утримувані для } \\
\text { продажу, та групи вибуття, тис. грн. } \\
\text { - в \% до активів }\end{array}$} & \multirow[t]{2}{*}{1200} & - & - & - & - \\
\hline & & - & - & - & $\mathrm{X}$ \\
\hline
\end{tabular}

* Складено та розраховано авторами на підставі даних фінансової звітності підприємства АПК

Дослідження показників табл. 1 показують, що звітному році порівняно 3 попереднім активи підприємства збільшились на на 18,6\%. Це відбулось за рахунок збільшення: необоротних активів на 43,8\% i оборотних активів на $6,9 \%$. В структурі активів підприємства попереднього року найбільшу питому вагу займали оборотні активи - 68,2\% та їх величина питомої ваги зменшились на 6,7\% за рахунок майже всіх елементів.

Аналіз стану, динаміки та структури розміщення оборотного капіталу в елементах оборотних активів підприємства $є$ важливим та здійснюється на підставі даних форм №1«Баланс
(Звіт про фінансовий стан)» та №5 «Примітки до річної фінансової звітності» за допомогою табл. 2.

3 табл. 2 видно, що в звітному році порівняно 3 попереднім оборотні активи підприємства збільшились на 8183 тис.грн або на 6,9\%, що відбулось за рахунок збільшення запасів на $15,4 \%$ та інших оборотних активів на 100\%, також зменшення дебіторської заборгованості на 10,9\% та грошових коштів та поточних фінансових інвестицій на $61,4 \%$, що є негативною тенденцією. В структурі оборотних активів на початок звітного року найбільшу питому питому вагу займали запаси - 92,2\%, питома вага грошових коштів та поточних фінансових інвестицій- 
Таблиця 2

Аналіз складу, структури та динаміки оборотних активів*

\begin{tabular}{|c|c|c|c|c|c|c|c|c|c|}
\hline \multirow[b]{2}{*}{ Показники } & \multirow[b]{2}{*}{ Код рядка } & \multicolumn{2}{|c|}{$\begin{array}{c}\text { Абсолютна } \\
\text { величина }\end{array}$} & \multicolumn{2}{|c|}{$\begin{array}{r}\text { Питома } \\
\text { вага, \% } \\
\end{array}$} & \multicolumn{4}{|c|}{ Відхилення } \\
\hline & & 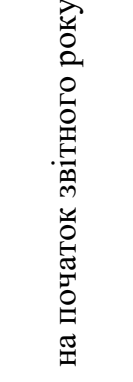 & 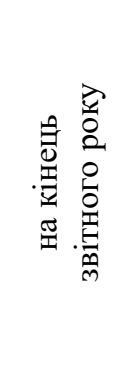 & 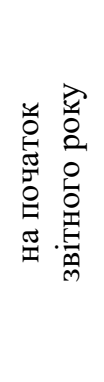 & 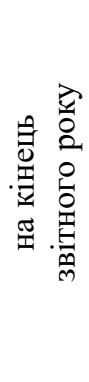 & 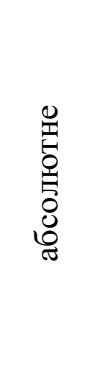 & 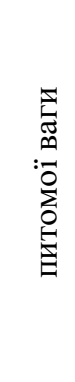 & 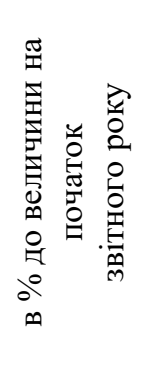 & 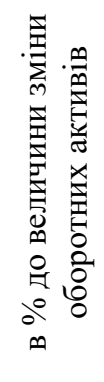 \\
\hline $\begin{array}{l}\text { Оборотні активи } \\
\text { всього, тис. грн., } \\
\text { в тому числі: }\end{array}$ & 1195 & 118630 & 126813 & 100 & 100 & 8183 & $\mathrm{x}$ & 6,9 & 100 \\
\hline - запаси & $1100 ; 1110$ & 101411 & 116987 & 85,5 & 92,2 & 15576 & 6,8 & 15,4 & 190,3 \\
\hline $\begin{array}{l}\text { - дебіторська } \\
\text { заборгованість }\end{array}$ & $1120 \div 1155$ & 5253 & 4683 & 4,4 & 3,7 & -570 & $-0,7$ & $-10,9$ & $-7,0$ \\
\hline $\begin{array}{l}\text { - грошові кошти та } \\
\text { поточні фінансові } \\
\text { інвестиції }\end{array}$ & 1160,1165 & 11966 & 4613 & 10,1 & 3,6 & -7353 & $-6,4$ & $-61,4$ & $-89,9$ \\
\hline $\begin{array}{l}\text { - інші оборотні } \\
\text { активи }\end{array}$ & 1170,1190 & - & 530 & - & 0,42 & 530 & 0,4 & - & 6,5 \\
\hline
\end{tabular}

* Складено та розраховано авторами на підставі даних фінансової звітності підприємства АПК

10,1\%, дебіторської заборгованості - 4,4\%, інших оборотних активів на підприємстві не було. На кінець звітного року відбулись наступні зміни в структурі оборотних активів: збільшилась питома вага запасів до 92,2\%, з'явились інші оборотні активи і питома вага їх склала - 0,42\%; відбулось зменшення питомої ваги дебіторської заборгованості - до 3,7\%, грошові кошти та поточні фінансові інвестиції - до 3,6\%.
Для аналіз структури розміщення оборотного капіталу за сферами розміщення його окремих елементів здійснюється за на підставі даних форм №1《Баланс (Звіт про фінансовий стан)» та №5 «Примітки до річної фінансової звітності» за допомогою табл. 3 .

Таблиця 3

Аналіз структури розміщення оборотного капіталу підприсмств*

\begin{tabular}{|c|c|c|c|c|c|c|c|}
\hline \multirow{2}{*}{ Показники } & \multicolumn{2}{|c|}{ Попередній рік } & \multicolumn{2}{|c|}{ Звітний рік } & \multicolumn{3}{|c|}{ Відхилення } \\
\hline & тис грн & $\%$ & тис грн & $\%$ & абс. & $\%$ & $\begin{array}{c}\text { за } \\
\text { стпуктурою }\end{array}$ \\
\hline $\begin{array}{l}\text { 1. Сфера виробництва } \\
\text { в тому числі: }\end{array}$ & 49834 & 42,01 & 50771 & 40,04 & 937 & 1,9 & -2 \\
\hline - виробничі запаси* & 21887 & 18,4 & 24849 & 19,6 & 2962 & 13,5 & 1,1 \\
\hline - незавершене виробництво* & 21661 & 18,3 & 21368 & 16,8 & -293 & $-1,3$ & $-1,4$ \\
\hline - поточні біологічні активи & 6286 & 5,3 & 4024 & 3,2 & -2262 & -36 & $-2,1$ \\
\hline - витрати майбутніх періодів & - & - & 530 & 0,4 & 530 & - & 0,4 \\
\hline $\begin{array}{l}\text { 2. Сфера обігу } \\
\text { в тому числі: }\end{array}$ & 68796 & 57,9 & 76042 & 59,9 & 7246 & 10,5 & 2 \\
\hline - готова продукція* & 51576 & 43,5 & 66745 & 52,6 & 15169 & 29,4 & 9,2 \\
\hline - грошові кошти & 11966 & 10,1 & 4613 & 3,6 & -7353 & $-61,4$ & $-6,4$ \\
\hline - дебіторська заборгованість & 5253 & 4,4 & 4683 & 3,7 & -570 & $-10,8$ & $-0,7$ \\
\hline - товари* & 1 & - & 1 & - & - & - & - \\
\hline - інші** & - & - & 0 & - & - & - & - \\
\hline Всього оборотний капітал & 118630 & 100 & 126813 & 100 & 8183 & 6,9 & - \\
\hline
\end{tabular}

*Складено та розраховано авторами на підставі даних фінансової звітності підприємства АПК 
3 табл. 3 видно, що в звітному році порівняно 3 попереднім загальна величина оборотного капіталу підприємства збільшилось на 8183 тис.грн. або на 6,9\%, що відбулось за рахунок збільшення капіталу, розміщеного в сфері виробництва на 937 тис.грн або на 1,9\% і в сфері обігу на 7246 тис.грн. або на 10,5\%. В структурі оборотного капіталу попереднього року, який вкладено в його оборотні активи, найбільшу питому вагу займає капітал, розміщений у сфері обігу - 57,9\%, питома вага капіталу, розміщеного в сфері виробництва склала 42,01\%. В звітному році відбулись наступні зміни в структурі оборотного капіталу: зменшилась питома вага капіталу, розміщеного в сфері виробництва та відповідно збільшилась питома вага капіталу, розміщеного в сфері обігу на 2\% пункти.

Аналіз оборотного капіталу, який вкладено в елементи оборотних активів підприємства, не пожливий без аналізу ефективності його викоритання та його окремих елементів (табл 4).

Таблиця 4

Аналіз використання оборотних активів *

\begin{tabular}{|c|c|c|c|c|c|}
\hline \multirow{2}{*}{ Показники } & \multirow{2}{*}{$\begin{array}{c}\text { Код рядка } \\
\text { (алгоритм розрахунку) }\end{array}$} & \multirow{2}{*}{$\begin{array}{l}\text { Попередн } \\
\text { ій рік }\end{array}$} & \multirow{2}{*}{$\begin{array}{l}\text { Звітний } \\
\text { рік }\end{array}$} & \multicolumn{2}{|c|}{ Відхилення } \\
\hline & & & & абс. & $\%$ \\
\hline $\begin{array}{l}\text { 1. Чистий дохід від реалізації продукції } \\
\text { (товарів, робіт, послуг), тис. грн. }\end{array}$ & $\begin{array}{l}\text { Ф № } 2 \\
\text { p. } 2000\end{array}$ & 138041 & 147489 & 9448 & 6,8 \\
\hline $\begin{array}{l}\text { 2. Середньорічні залишки оборотних } \\
\text { коштів, * тис. грн., в т.ч. }\end{array}$ & $\begin{array}{l}\text { Ф № } 1 \\
\text { p. } 1195\end{array}$ & 109123 & 122721,5 & 13598,5 & 12,5 \\
\hline 2.1. Запаси* & $\Phi$ № 1, p.1100 & 96902 & 109199 & 12297 & 12,7 \\
\hline 2.2. Кошти в розрахунках* & $\Phi$ № 1 p. $1125 \div 1155$ & 4154 & 4968 & 814 & 19,6 \\
\hline $\begin{array}{l}\text { 2.3. Грошові кошти та поточні } \\
\text { фінансові інвестиції* }\end{array}$ & $\begin{array}{c}\text { Ф № 1, } \\
\text { p.1160, 1165 }\end{array}$ & 8067 & 8289,5 & 222,5 & 2,76 \\
\hline 2.4. Інші оборотні активи* & Ф № 1, p.1170, 1190 & - & 265 & 265 & - \\
\hline 3. Кількість днів в періоді & $\mathrm{x}$ & 360 & 360 & $\mathrm{x}$ & $\mathrm{x}$ \\
\hline 4. Одноденна виручка, тис. грн.. & p. $1:$ p. 3 & 383,45 & 409,7 & 26,2 & 6,8 \\
\hline $\begin{array}{l}\text { 5. Потреба в оборотних коштів одного } \\
\text { дня, тис. грн. }\end{array}$ & p. $2:$ p. 3 & 303,1 & 340,9 & 37,8 & 12,5 \\
\hline 6. Кредиторська заборгованість, тис. грн. & $\Phi$ № 1 p.1615 & 39 & - & -39 & - \\
\hline 7. Коефіцієнт оборотності & p.1:p.2 & 1,3 & 1,2 & $-0,1$ & -5 \\
\hline 8. Коефіцієнт завантаженості & p. $2:$ p. 1 & 0,8 & 0,83 & 0,04 & 5,3 \\
\hline 9. Тривалість 1 обороту, днів, в т.ч. & $\begin{array}{l}\text { p. } 3: \text { p.7 або } \\
\text { p. } 2: \text { p. } 4\end{array}$ & 284,6 & 299,6 & 15 & 5,3 \\
\hline 9.1. В запасах & p.2.1:p.4 & 252,7 & 266,5 & 13,8 & 5,5 \\
\hline 9.2. В коштах в розрахунках & p.2.2:p.4 & 10,8 & 12,1 & 1,3 & 11,9 \\
\hline 9.3. В грошових коштах & p.2.3:p.4 & 21,04 & 20,2 & $-0,8$ & $-3,8$ \\
\hline 9.4. В інших оборотних коштах & p. $2.4:$ p.4 & - & 0,6 & 0,6 & - \\
\hline $\begin{array}{l}\text { 10. Економія (надлишок) оборотних } \\
\text { коштів, тис. грн. }\end{array}$ & $\begin{array}{l}\text { абс. відхилення по р.9 } \\
\text { ·p.5 за звітний рік }\end{array}$ & $\mathrm{x}$ & 5113,5 & $\mathrm{x}$ & $\mathrm{X}$ \\
\hline
\end{tabular}

* Складено та розраховано авторами на підставі даних фінансової звітності підприємства АПК

Дослідження показників табл. 4 показало, що ефективність використання оборотних активів підприємства в звітному році порівняно з попереднім погіршилась, про що свідчить зменшення коефіцієнту оборотності на 0,1 обороти, збільшення коефіцієнту завантаженості на 0,04 та збільшення тривалості одного обороту оборотних коштів на 15 днів (за рахунок збільшення: часу перебування коштів в запасах - на 13,8 днів, коштів в розрахунках - на 1,3 дня, в інших оборотних коштах - на 0,6 дня). Це призвело до залучення додаткової суми оборотних коштів у розмірі 5113,5 тис. грн.

Для більш детального аналізу стану, структури, динаміки та ефективності використання оборпотних активів підприємства необхідно проводити більш детальний аналіз за його окремими елементами [6, с. 200-203], а також аналіз наявності власних оборотних активів (власного оборотного капіталу), як джерел фінансування запасів та фінансової стійкості підприємства (табл. 5).

Дані розрахунків, які наведені в табл. 5 показують, що фінансова ситуація на підприємстві на початок і на кінець попереднього року $є$ абсолютно стійкою, тому що власних оборотних коштів достатньо для покриття запасів, що позитивно характеризує діяльність підприємства в цей період, але на кінець звітного року ситуація на підприємстві змінилась на не стійку у звязку 3 тим, що джерел послабляючих фінансову напругу вистачає на покриття запасів, але не достатньо власних оборотних активів, що є негативним. 
Таблиця 5

Аналіз фінансової стійкості підприсмства за узагальнюючими показниками*

\begin{tabular}{|c|c|c|c|}
\hline \multirow[b]{2}{*}{ Показники (за кодом рядка Форми №1) } & \multicolumn{3}{|c|}{ Сума, тис.грн. } \\
\hline & $\begin{array}{c}\text { на початок } \\
\text { поперед. Року }\end{array}$ & $\begin{array}{c}\text { на кінець } \\
\text { поперед. } \\
\text { року }\end{array}$ & $\begin{array}{c}\text { на кінець } \\
\text { звітного } \\
\text { року }\end{array}$ \\
\hline 1. Власний капітал (1495) & 143679 & 172835 & 193781 \\
\hline 2. Необоротні активи (1095) & 46812 & 55293 & 79503 \\
\hline $\begin{array}{l}\text { 3. Наявність власні оборотні активи (власний оборотний } \\
\text { капітал) (1495-1095) }\end{array}$ & 96867 & 117542 & 114278 \\
\hline 4. Короткострокові кредити банків (1600) & 0 & 0 & 0 \\
\hline $\begin{array}{l}\text { 5. Загальна величина джерел формування запасів (ряд. } 3 \\
+ \text { ряд. } 4)\end{array}$ & 96867 & 117542 & 114278 \\
\hline 6. Запаси $(1100 ; 1110)$ & 92393 & 101411 & 116987 \\
\hline $\begin{array}{l}\text { 7. Надлишок (+) або нестача (-) власних обо-ротних } \\
\text { коштів (ряд. } 3 \text { - ряд. } 6)\end{array}$ & 4474 & 16131 & -2709 \\
\hline $\begin{array}{l}\text { 8. Надлишок (+) або нестача (-) загальної вели-чини } \\
\text { джерел формування запасів (ряд.5 - ряд.6) }\end{array}$ & 4474 & 16131 & -2709 \\
\hline $\begin{array}{l}\text { 9. Джерела, що послаблюють фінансову напругу } \\
\text { (р. 1615) }\end{array}$ & 206 & 39 & 0 \\
\hline 10. Тип фінансової ситуації на підприємстві & абс.стійка & абс.стійка & не стійка \\
\hline
\end{tabular}

* Складено та розраховано авторами на підставі даних фінансової звітності підприємства АПК

На нашу думку, аналіз використання оборотних активів підприємства не можливий без таких показників, як оборотність та тривалість обороту окремих елементів оборотних активів - запасів (в тому числі виробничих запасів, незвершеного виробництва, готової продукції), дебіторської заборгованості , грошових коштів та поточних фінансових інвестицій, а також тривалості фінансового циклу підприємства і співвідношення дебіторської та кредиторської заборгованості за запропонованим методичним підходом та системою показників [7, с. 43-53]. Фінансовий цикл підприємства розраховується для визначення обороту грошових коштів, інвестованих в оборотний капітал, починаючи з моменту погашення кредиторської заборгованості за отримані виробничі запаси, i закінчуючи інкасацією дебіторської заборгованості за поставлену готову продукцію, та необхідний для управління джерелами фінансування основної діяльності підприємства.

На нашу думку, фінансовий аналіз оборотних активів підприємства та його елементів є першим інструментом та забезпечующим ефективність процесу управління, так як визначає стан, ефективність використання, тенденції змін, вплив негативних та позитивних факторів для застосування таких інструментів управління, як управлінський облік та аудит спеціального призначення.

Аналіз праць вчених показав, що за результатами дослідження структури управлінського обліку, його основних функцій, порядку застосування і функціонування в економічно розвинутих країнах, вчені в Україні прийшли до висновку, що управлінський облік є однією зі складових системи управління суб' єктів на носить не тільки внутрішньогосподарський напрям, але вектор його застосування змінився на стратегічний, тобто такий, що враховує вплив факторів зовнішнього середовища на діяльність суб'єктів, їх конкурентів та можливості забезпечення конкурентоспроможності та ефективності функціонування [8, c. 233-243, 301-302].

Так, вчені визначають сучасний управлінський облік, як:

- облік, спрямований на підтримку стратегічно орієнтованих рішень, тісно пов'язаний з ринково орієнтованою зовнішньою інформацією, яка має як фінансовий, так і нефінансовий характер, спрямований не тільки на фіксацію конкретних фактів, а більше на вистежуванням трендів, тенденцій або суттєвих змін, оперує плановими і прогнозними даними довгострокового характеру [9];

- управлінський облік - це підсистема обліку, функція стратегічного управління, яка забезпечує менеджерів інформацією про внутрішнє середовище діяльності суб'єктів для прийняття стратегічних рішень [10].

Наше дослідження показало [8, с. 235], що О.О. Довжик вважає [11], що управлінський облік $\epsilon$ ефективним інструментом управління, тому що створює конкурентні переваги в ринковому середовищі, а саме: забезпечує суб'єктів ключовою інформацією, а досвід підприємств України свідчить, що практичне застосування управлінського обліку, на жаль, ще не набуло належного поширення, у зв'язку з невирішеним колом проблем. У сучасних умовах це питання вкрай актуальне і потребує свого дослідження.

Таким чином, проведене наше дослідження підтверджує можливість застосування управлінського обліку, який носить як внутрішньогосподарський, так й стратегічний характер, у суб'єктів господарювання для здійснення механізму управління їх діяльністю в контексті забезпечення конкурентоспроможності та ефективності їх функціонування.

Ще одним інструментом управління як оборотними активами підприємства, так й всіма 
елементами та результатами його діяльності, може бути і внутрішній аудит, якій застосовується на підприємстві та для суб'єктів малого бізнесу (може бути використаний і суб'єктами великого та середнього бізнесу) більш ефективним та менш витратним буде застосування саме зовнішнього аудиту спеціального призначення - аудиту ефективності, або консалтингу, для оцінки результативності діяльності підприємств та використання ресурсів, конкурентоспроможності та ефективності функціонування для їх забезпечення та розвитку діяльності, що активно використовується в економічно розвинутих країнах [8, с. 236-243].

Наше дослідження показало [8, с. 236-243], що зарубіжна практика проведення аудиту підтверджує необхідність застосування на підприємствах аудиту ефективності - аудиту спеціального призначення, де такий аудит застосовується досить широко.
Ефективний аудит, на думку авторів [12, с. 195], - це «системний, цілеспрямований і організований процес отримання експертно-аналітичної оцінки об'єктивних даних про результативність, економічність і продуктивність економічної діяльності аудированої одиниці 3 метою встановлення рівня відповідальності цих даних певним критеріям і на підставі цього обгрунтування твердження про ефективність (результативність, економічність, продуктивність).

На нашу думку, управління оборотними активами підприємства не можливе без таких інструментів управління, як фінансовий аналіз, управлінський облік та аудит спеціального призначення, що базуються на класичних функціях управління - аналіз, облік та контроль (рис. 1), та не можливі без ефективного планування та такої часткової функції управління, як моніторинг.

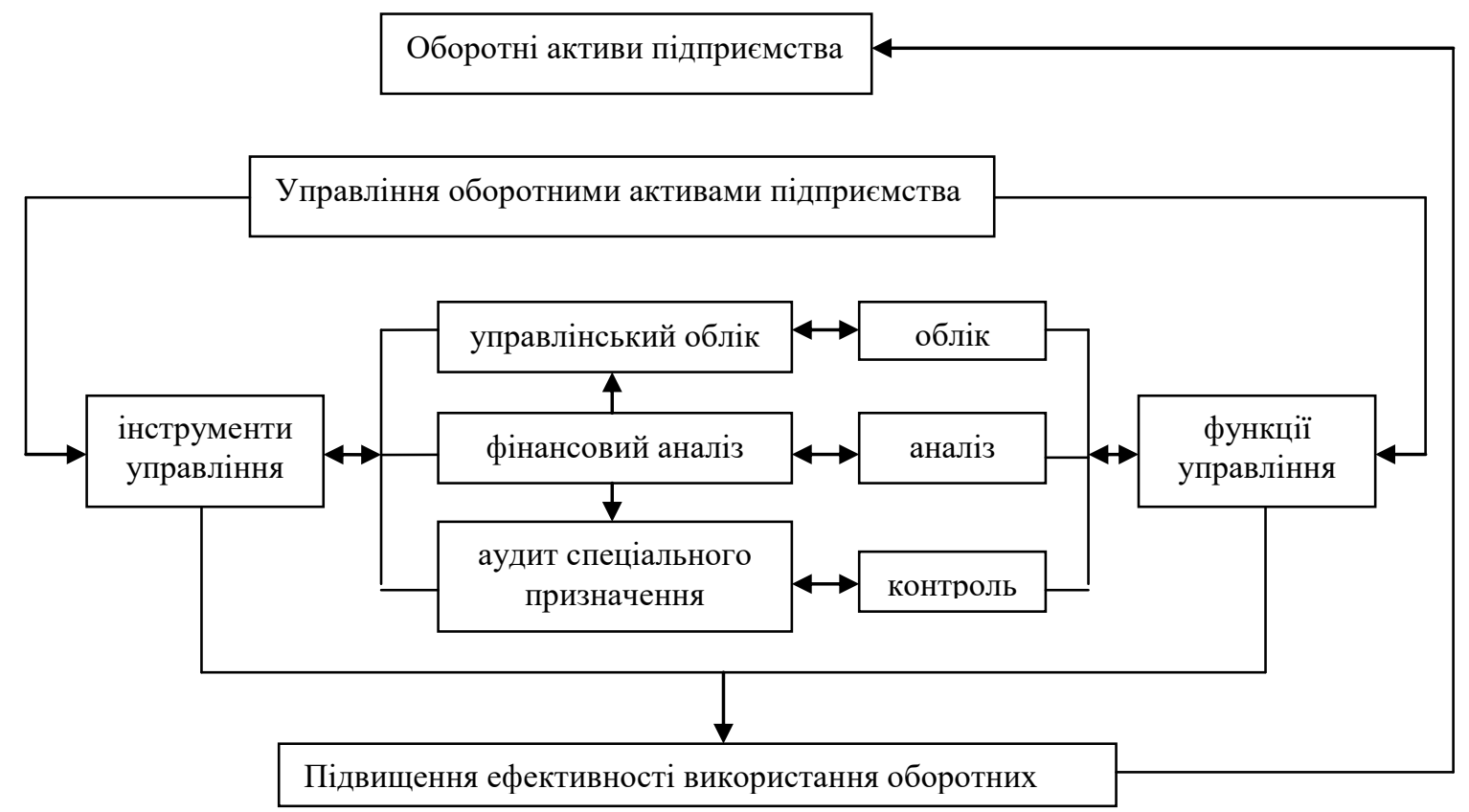

Рис. 1 - Склад інструментів в системі управління оборотними активами підприємства* * складено авторами

Моніторинг необхідний для постійного спостереження та оперативного управління станом та ефективністю використання не тільки окремими елементами оборотних активів, та й всією діяльністю підприємства і iї результатами для забезпечення ефективності функціонування підприємства та йцого конкурентоспроможності.

Висновки та перспективи подальших досліджень. Проведене дослідження підтверджує необхідність управління оборотними активами підприємства та результати проведеного дослідження дозволило отримати певні результати і зробити наступні висновки:

- оборотні активи підприємств, в тому числі підприємств промисловості, мають велику питому вагу в загальній сукупності активів та мають дефіцит власних джерел фінансування, що негативно впливає на фінансовий стан підприємства та потребує пошуку інструментів управління в системі управління діяль- ністю суб'єктів господарювання;

- ефективне управління об'єктом діяльності будь-якого підприємства починається 3 якісного економічного аналізу, який формує його напрями, вибір інструментів та методів у зв'язку з виявленими негативними та позитивними тенденціями на підставі сформованої системи показників, а аналіз стану, структури, динаміки, ефективності використання оборотних активів підприємства та його елементів не можливий без такого інструменту управління, як фінансовий аналіз;

- на нашу думку, аналіз використання оборотних активів підприємства охоплює не тільки аналіз стану, структури, динаміки, ефективності використання оборотних активів підприємства в цілому, але й аналіз стану, структури, ефективності використання окремих елементів оборотних активів - запасів (в тому числі виробничих запасів, незвершеного виробництва, готової продукції), дебіторської заборго- 
ваності, грошових коштів та поточних фінансових інвестицій, а також тривалості фінансового циклу підприємства і співвідношення дебіторської та кредиторської заборгованості - запропонованим нами методичним підходом;

- дослідження публікацій вчених показало, що управління оборотними активами підприємства не можливе без таких інструментів управління, як фінансовий аналіз, управлінський облік та аудит спеціального призначення, що, на нашу думку, базуються на класичних функціях управління - аналіз, облік та контроль, та не можливі без ефективного планування та такої часткової функції управління, як моніторинг. - напрямами подальшого дослідження $\epsilon$ формування системи часткових показників використання елементів оборотних активів та розрахунку фінансового циклу підприємства в запропонованому методичному підході до проведення фінансового аналізу оборотних активів підприємства, що сприяє ефективному управлінню діяльністю підприємств та забезпеченню їх функціонування та конкурентоспроможності.

\section{Література}

c.

1. Статистичний щорічник України за 2019 рік // Державна служба статистики України. Київ. 2020. 482

2. Черниш С.С. Економічний аналіз: навч. посіб. Київ: Центр учбової літератури, 2010. 312 с.

3. Цал-Цалко Ю.С. Фінансовий аналіз: підручник. Київ: ЦУЛ, 2008. 556 с. 2016. 304 c.

4. Лучко М.Р., Жукевич С.М., Фаріон А.І. Фінансовий аналіз: навчальний посібник. Тернопіль: ТНЕУ,

5. Фінансовий аналіз: навч. посіб. / Білик М.Д. та ін. 2-ге вид. Київ: КНЕУ, 2014. 592 с.

6. Антонюк О.П., Ступницька Т.М., Купріна Н.М. Економічний аналіз: навчальній посібник. 3-те вид. стереотипне. Львів: «Магнолія 2006», 2015. 326 с.

7. Куприна Н.М. Совершенствование механизма управления оборотным капиталом в пищевой промышленности: дис. ... к.э.н.: 08.07.01: защита 28.04.2006 / Наук. рук. А.И. Бутенко. Одесса: ИППРЭЭИ НАНУ, 2006. $231 \mathrm{c}$.

8. Купріна Н.М. Забезпечення конкурентоспроможності харчової промисловості України: теорія і практика: монографія. Одеса: Видавничий дім «Гельветика», 2019. 304 с.

9. Панков В.В., Несветайло В.Ф. Базові принципи і допущення стратегічного управлінського обліку // Міжнародний бухгалтерський облік. 2012. № 7. С. 2 - 7.

10. Семанюк В.З. Формування підсистеми стратегічного обліку в умовах ринкових відносин // Формування ринкових відносин в Україні: зб. наук. праць. Київ, 2010. Вип. 11(114). С. 59-64.

11. Довжик О.О. Роль управлінського обліку та проблеми його впровадження на підприємствах // Вісник. 2012. № 2. URL: http://dev.pdaa.edu.ua/sites/default/files/visnyk /2012/ 02/174.pdf. (дата звернення: 08.03.2019). doi: 10.31210/visnyk2012.02.34

12. Захарченко B.I., Меркулов М.М., Балахонова О.В. Моделі і методи прийняття рішень в аналізі та аудиті: навч. посіб. Львів: «Магнолія 2006», 2012. 352 с.

Стаття надійшла 20.03.2021

Стаття прийнята до друку 3.04.2021

Доступно в мережі Internet 21.07.2021

Kuprina N.

Doctor of Economics, Associate Professor

Department of Accounting and Auditing

E-mail:k.natali_@ukr.net

ORCID ID: 0000-0003-4645-545X

\section{Baraniuk Kh.}

Ph.D., Assistant

Department of Accounting and Auditing

E-mail: baranyuk.kristina@gmail.com

ORCID ID: 0000-0002-3346-0332

\section{Stupnytska T.}

Ph.D., Associate Professor

Department of Accounting and Auditing

E-mail: t.stupnitska@gmail.com

ORCID ID: 0000-0002-2517-2795

Velychko 0.

The student of the third grade of Economy, Business and Control Faculty Odessa National

Odessa National Academy of Food Technologies

Kanatna str., 112, Odesa, Ukraine, 65039

E-mail: velichko20012001@gmail.com

ORCID ID: 0000-0002-8591-878X

\section{CURRENT ASSETS IN THE ENTERPRISE MANAGEMENT SYSTEM: MODERN ASPECTS OF ACCOUNTING, ANALYSIS AND AUDIT}

Relevant in modern conditions for the effective functioning of enterprises is to determine the areas of management of its current assets, which have a large share in the total assets and the lack of own sources of funding, which negatively affects the financial condition of the enterprise. 
Effective management of the object of activity of any enterprise begins with a qualitative economic analysis, which forms its directions, the choice of tools and methods in connection with the identified negative and positive trends on the basis of the existing system of indicators, and analysis of the state, structure , dynamics, efficiency of current assets of the enterprise and its elements is not possible without such a management tool as the financial analysis. A methodical approach to the financial analysis of current assets of the enterprise has been proposed, which includes not only the analysis of the state, structure, dynamics, efficiency of current assets of the enterprise as a whole, but also the analysis of the state, structure, efficiency of use of current assets inventories,(including productive stocks, work in progress, finished goods), receivables, cash and current financial investments, as well as the duration of the financial cycle of the enterprise and the ratio of receivables and payables.

It has been substantiated that the management of current assets of the enterprise is not possible without such management tools as financial analysis, management accounting and special purpose audit, which, in our opinion, are based on the classic management functions - analysis, accounting and control, and are not possible without effective planning and such a partial management function as monitoring.

Key words: current assets, working capital, enterprise, management accounting, financial analysis, special purpose audit, management tools, management functions, indicators of efficiency.

\section{References}

1. Statystychnyi shchorichnyk Ukrainy za 2019 rik. (2020). Derzhavna sluzhba statystyky Ukrainy.

2. Chernysh, S. S. (2010). Ekonomichnyi analiz. Tsentr uchbovoi literatury.

3. Tsal-Tsalko, Yu. S. (2008). Finansovyi analiz. TsUL, 2008.

4. Luchko, M. R., Zhukevych, S. M., \& Farion, A. I. (2016). Finansovyi analiz. TNEU.

5. Bilyk, M. D. (2014). Finansovyi analiz (2nd ed.). KNEU. 2006».

6. Antoniuk, O. P., Stupnytska, T. M., \& Kuprina, N. M. (2015). Ekonomichnyi analiz (3nd ed.). «Mahnoliia

7. Kuprina, N. M. (2006). Sovershenstvovanie mehanizma upravleniya oborotnyim kapitalom v pischevoy promyishlennosti (dissertation). IPPREEI NANU, Odesa.

8. Kuprina, N. M. (2019). Zabezpechennia konkurentospromozhnosti kharchovoi promyslovosti Ukrainy: teoriia i praktyka. Vydavnychyi dim «Helvetyka».

9. Pankov, V. V., \& Nesvetailo, V. F. (2012). Bazovi pryntsypy i dopushchennia stratehichnoho upravlinskoho obliku. Mizhnarodnyi bukhhalterskyi oblik, (7), 2 - 7 .

10. Semaniuk, V. Z. (2010). Formuvannia pidsystemy stratehichnoho obliku v umovakh rynkovykh vidnosyn. Formuvannia rynkovykh vidnosyn v Ukraini, (11(114), 59-64.

11. Dovzhyk, O. O. (2012). Rol upravlinskoho obliku ta problemy yoho vprovadzhennia na pidpryiemstvakh. Visnyk, (2). http://dev.pdaa.edu.ua/sites/default/files/visnyk /2012/ 02/174.pdf. doi: 10.31210/visnyk2012.02.34

12. Zakharchenko, V. I., Merkulov, M. M., \& Balakhonova, O. V. (2012). Modeli i metody pryiniattia rishen v analizi ta audyti. «Mahnoliia 2006».

Received 25 April 2021

Approved 8 May 2021

Available in Internet 21.07.2021

Цитування згідно ДСТУ 8302:2015

Купріна Н.М., Ступницька Т.М., Баранюк Х.О., Величко О.М. Оборотні активи в системі управління підприємства: сучасні аспекти обліку, аналізу та аудиту // Економіка харчової промисловості. 2021. Т. 13, вип. 2. С. 50-

57. doi: $10.15673 /$ fie.v13i2.2040

Cite as APA style citation

Kuprina, N., Stupnytska, T., Baraniuk, Kh., \& Velychko, O. (2021). Current assets in the enterprise management system: modern aspects of accounting, analysis and audit. Food Industry Economics, 13(2), 50-57. doi: 10.15673/fie.v13i2.2040 